\title{
PENYULUHAN BUDIDAYA IKAN MOLLY PADA REMAJA SAAT PANDEMI SEBAGAI ALTERNATIF PENGISI WAKTU YANG PRODUKTIF
}

\author{
Nanda Diniarti*, M. Junaidi, Nunik Cokrowati, Laily Fitriani Mulyani \\ ${ }^{1}$ Prodi Budidaya Perairan, Fakultas Pertanian Universitas Mataram
}

Jalan Pendidikan No.37 Gedung H (Budidaya Perairan) Fakultas Pertanian UNRAM, Mataram 83125

\author{
*)alamat korespondensi: nandadiniarti@unram.ac.id
}

Keyword : Abstrak:

Budidaya, Saat pelaksanaan PPKM level 3 dan 4 membatasi kegiatan di luar rumah. Ikan molly, Banyak sektor tutup sementara terutama sektor informal bahkan kegiatan remaja, belajar mengajar dilakukan secara daring. Akhirnya banyak remaja berdiam pandemi, diri di rumah dan memanfaatkan waktu dengan bermain sosial media dan pengisi game online. Akibat terlalu sering bermain social media dan game online waktu banyak dampak negative yang timbul seperti pelecehan, pornografi bahkan kegiatan kriminal. Untuk itu diperlukan kegiatan yang bisa membawa manfaat yang lebih besar contohnya berbudidaya ikan hias. Ikan hias yang sedang banyak peminatnya salah satunya ikan Molly. Tujuan kegiatan ini adalah memberikan pengetahuan dan wawasan tentang budidaya ikan hias molly. Manfaat yang diharapkan agar para remaja dapat mengisi waktu dengan membudidayakan ikan molly Lokasi penyuluhan berada di Desa Gontoran Lombok Barat dengan sasaran remaja masjid. Kegiatan penyuluhan dilakukan dengan cara pendidikan orang dewasa. Hasil dari kegiatan penyuluhan Para remaja antusias untuk membudidayakan ikan molly karena di dukung banyaknya sumber pakan dan air yang melimpah. Bentuk ikan molly yang menarik juga menjadi daya tarik remaja untuk membudidayakan ikan molly. Banyaknya pertanyaan yang diberikan merupakan indikator keingin tahuan para remaja. Kesimpulan dari kegiatan adalah adanya peningkatan pengetahuan para remaja dalam hal budidaya ikan molly.

Panduan Sitasi (APPA $7^{\text {th }}$ edition) :

Diniarti, N., Junaidi, M., Cokrowati, N., \& Mulyani, L. F. (2022). Penyuluhan Budidaya Ikan Molly Pada Remaja Saat Pandemi Sebagai Alternatif Pengisi Waktu Yang Produktif. Jurnal Pengabdian Perikanan Indonesia, 2(1), 20-24. https://doi.org/10.29303/jppi.v2i1.640. 


\section{PENDAHULUAN}

Awal tahun 2020 dunia dilanda oleh pandemi Covid 19 yang berasal dari Wuhan Tiongkok dan menyebar secara cepat ke seluruh dunia. Penyebaran virus yang sangat cepat dan mengakibatkan banyak kematian menyebabkan banyak negara memberlakukan pembatasan akses keluar dan masuk wilayah sehingga semua aktivitas dilakukan dari rumah secara daring/online. Banyak sektor yang mendapat dampak negatifnya pandemi yaitu ekonomi, pemerintahan, pendidikan dll (Hakim et al., 2021). Salah satu efek pandemi Covid 19 adalah dimana anak sekolah menjalankan pembelajaran melalui online (Daring). Pesatnya perkembangan media sosial dan internet, membawa dampak signifikan bagi masyarakat baik dewasa maupun remaja diseluruh belahan dunia. Penggunaan smartphone semakin biasa karena salah satu perangkat untuk mengakses internet (Humirah et al., 2021).

Banyaknya waktu yang dihabiskan oleh usia remaja dalam mengakses internet baik dalam kegiatan sekolah daring maupun membuka media sosial memberikan banyak juga dampak negatif. Diantara dampak negatif dari penggunaan internet adalah kedisiplinan belajar remaja menurun, muncul stres dan kecemasan, serta kehilangan konsep diri (Sari et al., 2018). Tak jarang berita tentang seorang anak yang membeli paket untuk akses game online sampai ratusan ribu dimana uang diperoleh dari hasil mencuriuang orang tua. Bukan tindak kriminal saja yang terjadi tapi pelecehan seksual bahkan pornografi. Ini menggambarkan bahwa remaja telah banyak yang kecanduan internet. Waktu yang dihabiskan untuk mengakses internet harus perlahan-lahan di alihkan pada kegiatan yang lebih bermanfaat. Kegiatan yang bermanfaat untuk mengisi waktu remaja adalah kegiatan budidaya ikan hias. Ikan hias yang sedang banyak dicari adalah ikan molly.

Ikan hias molly merupakan ikan hias yang cara budidayanya relatif mudah dan murah. Budidaya molly dapat sebagai sampingan karena ikan ini bukan ikan hias rewel seperti koi. Pemeliharan molly di akuarium memang tidak terlalu menyulitkan (Razi, 2014). Selain itu ikan hias molly memiliki banyak memiliki keunggulan dibanding ikan hias lainnya. Menurut Trobosaqua (2020), ikan molly digandrungi para hobiis ikan hias karena bentuknya yang menarik, kecil, dan warnanya bervariasi. Kehadiran ikan hias yang satu ini terbilang wajib dalam akuarium, sebagai pelengkap koloni mewakili ikan ukuran kecil. Pasar molly juga banyak.

Budidaya ikan hias selain untuk menghilangkan stress juga sangat menjanjikan saat pandemi. Dikabarkan pada Media Indonesia pertanggal 17 Agustus 2020 bahwa permintaan ikan hias meningkat selama pandemi Covid 19. Hal ini seiring dengan semakin banyaknya masyarakat yang memilih hobi baru memelihara ikan hias selama Pembatas Social Berkala Besar (PSBB). Tujuan kegiatan ini adalah memberikan pengetahuan dan wawasan tentang budidaya ikan hias molly. Manfaat yang diharapkan setelah kegiatan ini adalah agar para remaja dapat mengisi waktu dengan membudidayakan ikan molly yang lebih menghibur serta dapat memberikan tambahan penghasilan.

\section{METODE KEGIATAN}

Pendekatan pelaksanaan kegiatan program Pengabdian Pada Masyarakat (PPM) sebagai solusi dari permasalahan yang dihadapi adalah dengan memberikan penyuluhan tentang bagaimana membudidayakan ikan molly secara sederhana pada khalayak sasaran. Dalam meningkatan pengetahuan dan pemahaman cara pembudidaya ikan molly, maka dilakukan penyuluhan terhadap khalayak sasaran yakni remaja yang tergabung dalam Kelompok Remaja Masjid Gontoran Daye. Materi penyuluhan yang diberikan antara lain: mengenali indukan molly yang baik, teknik mengawinkan, perawatan benih dan peningkatan kualitas ikan molly. Penyuluhan dilaksanakan dengan menggunakan 
metode Pendidikan Orang Dewasa (POD) dengan penekanan pada model komunikasi dua arah dengan pola tukar menukar pengalaman, diskusi kelompok, dan demonstrasi yang dilaksanakan dalam bentuk klasikal, sedangkan untuk meningkatkan pengetahuan psikomotorik sasaran dilaksanakan praktek secara mandiri di luar kelas. Selain itu khalayak sasaran juga diberikan Teknologi Tepat Guna (TTG) Budidaya Molly. Kegiatan ini difasilitasi oleh Kelompok Remaja Masjid Gontoran Daye baik tempat pelaksanaan dan peserta penyuluhan.

\section{HASIL DAN PEMBAHASAN}

Kegiatan penyuluhan dilaksanakan pada tanggal 28 Agustus 2021 bertempat di salah seorang peserta penyuluhan. Peserta penyuluhan yang hadir sebanyak 22 orang. Pelaksanaan penyuluhan dilakukan dengan melakukan protokol kesehatan sehingga jumlah peserta dibatasi mengingat luasan tempat kegiatan. Tim kegiatan terdiri dari 4 orang dosen Program studi Budidaya Perairan Universitas Mataram dan dibantu oleh 2 orang mahasiswa. Berikut adalah suasana kegiatan penyuluhan.

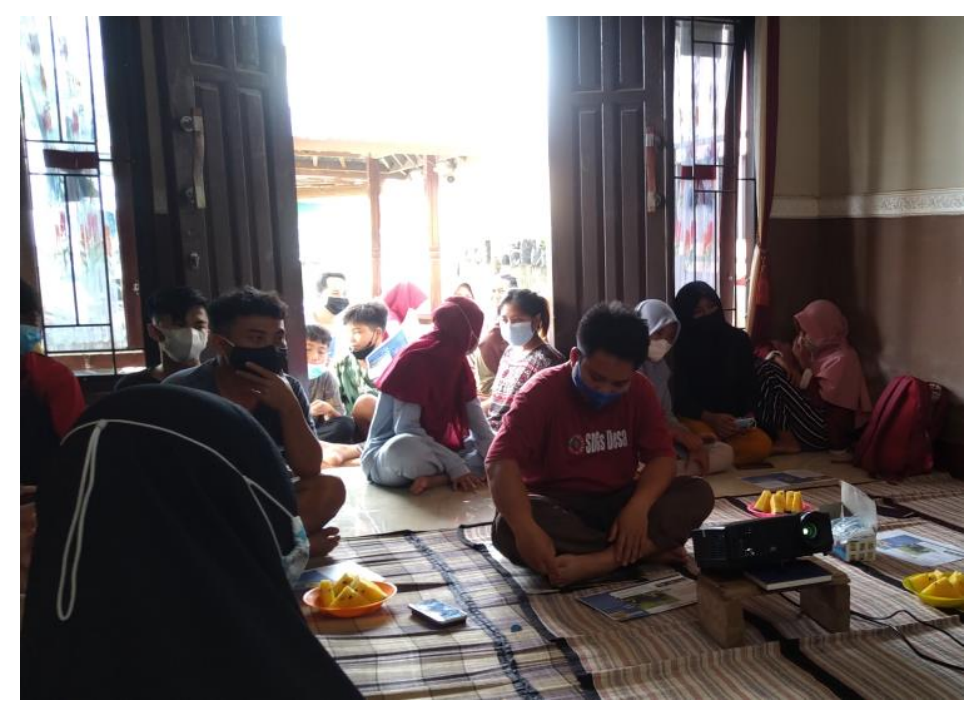

Gambar 1. Peserta kegiatan penyuluhan

Pada awal acara penyaji menanyakan apa saja aktivitas yang dilakukan oleh para remaja saat pandemi. Jawaban hampir seragam yaitu para remaja menghabiskan waktu luang yang banyak dengan membuka media sosial untuk bertukar kabar, mengunggah konten dan bermain e-sport dll. Penggunaan internet selama pandemi memang meningkat. Menurut Firdaus \& Dewi (2021), pengguna internet di Indonesia terbanyak pada rentang usia 15-19 tahun dan lebih dari 90\% adalah anak yang masih duduk di bangku Sekolah Menengah Atas (SMA). Berdasarkan Hasil survey Asosiasi Penyelenggara Jasa Internet Indonesia (APJI) dalam Firdaus \& Dewi (2021), remaja melakukan aktivitas menonton video online sebanyak $45,3 \%$, bermain game online $17,1 \%$, dan sisanya digunakan membuka media social dan aplikasi belanja. Kegiatan yang berhubungan dengan internet akan menjadikan remaja kecanduan yang ditandai dengan penggunaan internet melebihi 5 jam tiap hari. Kecanduan internet akan memberikan banyak dampak buruk salah satunya efikasi diri yag rendah. Efikasi diri merupakan keyakinan individu terhadap kemampuan yang ada dalam pemecahan masalah. Bahaya ini haruslah di kurangi dengan cara mengalihkan perhatian mereka pada aktivitas yang menyenangkan dan bermanfaat. Maka penyuluhan tentang budidaya ikan molly dilakukan.

Ikan molly merupakan salah satu ikan hias dan termasuk ikan live brearer (melahirkan) dan termasuk dalam golongan omnivora. Ukurannya beragam namum panjang standar maksimum $7,5 \mathrm{~cm}$ 
dan memiliki panjang tubuh rata-rata $4 \mathrm{~cm}$ (Fishbase, 2021). Bagi pemula, ikan molly ini layak dipelihara atau dibudidayakan. Sebab, cara merawatnya relatif mudah. Ikan ini hanya perlu pakan yang terus tersedia. Tidak sampai kehabisan dalam waktu cukup lama. Pakan yang paling baik itu cacing sutra. Namun, pelet juga bisa. Memelihara molly juga tidak mesti di dalam akuarium. Wadah pemeliharaan bisa menggunakan toples atau baskom (Anonim, 2021).

Setelah peserta mendengar pemaparan penyaji tentang ikan molly banyak juga yang tertarik utk mulai membudidayakan baik untuk sekedar mengisi waktu luang dan juga tertarik untuk dijual. Ikan molly harganya memang relatif murah, harga sekitar 2-5 ribu per ekor. Namun pada jenis dan corak yang langka maka harga bisa 10-20 ribu per ekor bahkan ada yang dihargakan 200 rb jika melihat tempat jual beli online. Selain mendengarkan penyuluhan tentang teknik budidaya ikan molly peserta juga mendapat TTG tentang rangkuman budidaya ikan molly. Teknologi tepat Guna yang diberikan disajikan pada gambar 2 .

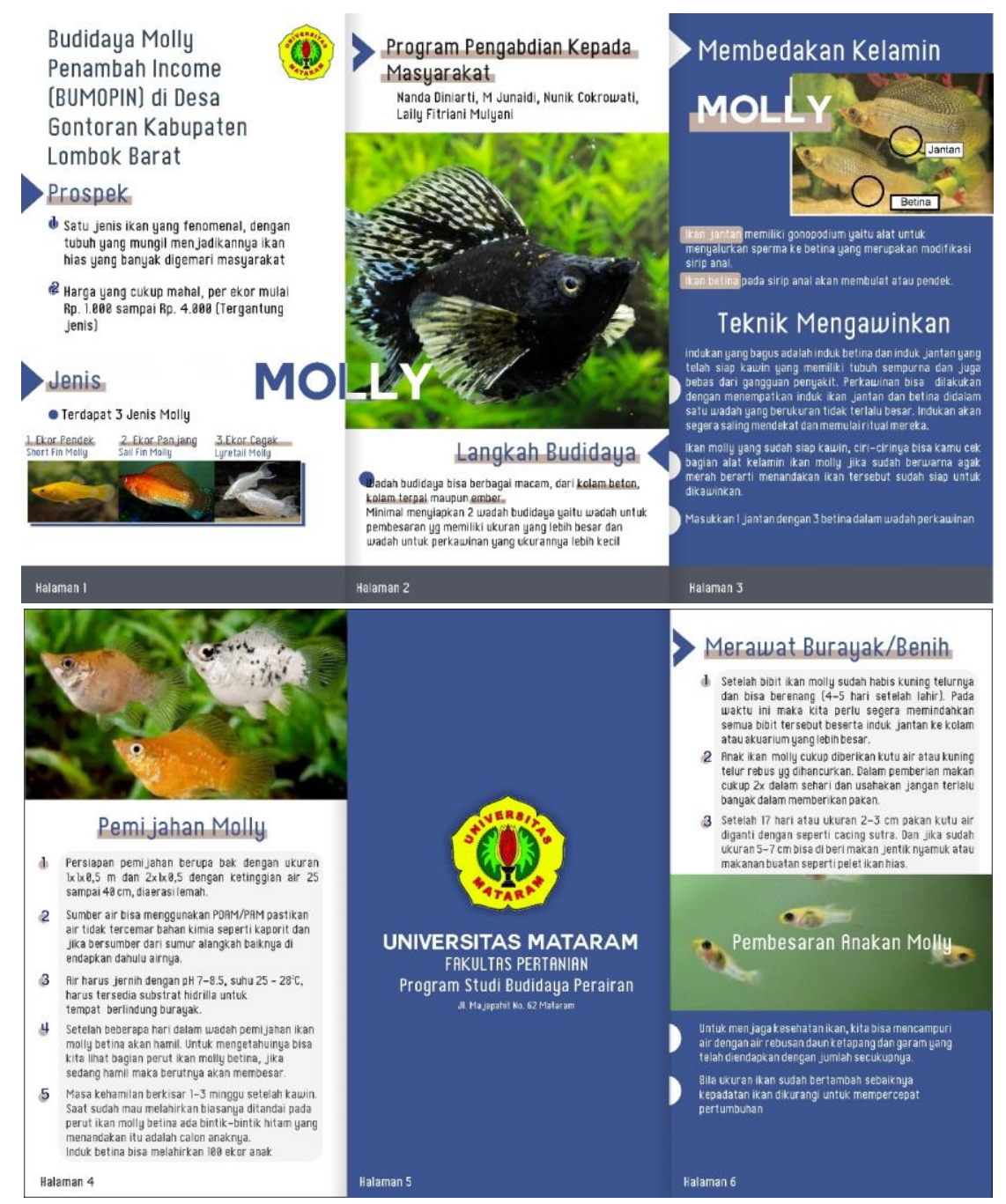

Gambar 2. Lembaran TTG penyuluhan

Saat penyuluhan banyak yang menanyakan tentang pakan apa yang baik diberikan. Pakan yang baik diberikan pada ikan dewasa adalah cacing sutra atau kutu air tapi pellet ikan hias kecil juga mau dikonsumsi oleh ikan molly. Pakan Ikan yang baru lahir karena bukaan mulut masih terbatas maka sebaiknya diberikan hancuran kuning telur rebus. Desa Gontoran memiliki potensi pakan ikan molly yang cukup melimpah yakni keberadaan cacing sutra di beberapa anak saluran irigasi, kutu air juga tersedia di kolam-kolam pemeliharaan ikan/sawah dan sumberdaya air yang memadai. 
Ada pula yang bertanya untuk mulai memelihara ikan molly bagi pemula baiknya membeli berapa ekor. Untuk pembudidaya pemula sebaiknya memelihara beberapa pasang indukan. Satu pasang indukan ikan molly terdiri dari 3 ekor betina dan 1 ekor jantan. Dan wadah pemeliharaan cukup disediakan 2 buah, 1 untuk pemeliharaan indukan dan wadah yang relatif kecil untuk memelihara anakan. Banyaknya pertanyaan mengindikasikan adanya minat remaja untuk mulai membudidayakan ikan molly.

\section{KESIMPULAN DAN SARAN}

Hasil kegiatan penyuluhan pada remaja masjid Desa Gontoran Daye didapatkan adanya peningkatan pengetahuan tentang budidaya ikan molly. Selain itu adanya ketertarikan untuk mulai membudidayakan terlihat dari pertanyaan teknis yang dilontarka pada penyaji.

Disarankan untuk adanya kegiatan membudidayakan ikan pada anak usia sekolah untuk mengurangi kecanduan akan internet sebagai pengisi waktu.

\section{UCAPAN TERIMA KASIH}

Penulis mengucapkan terima kasih kepada Universitas Mataram yang telah mendanai kegiatan ini melalui skim pengabdian kepada masyarakat PNBP Fakultas Pertanian tahun anggaran 2021.

\section{DAFTAR PUSTAKA}

Ginanjar D. 2021. Memelihara Ikan Molly Murah tapi Menyenangkan. www.jawapos.com/hobikesenangan/14/02/2021/memelihara-ikan-molly-murah-tapi-menyenangkan/?page=2, diakses 11 November 2021.

Fishbase. 2021. Poecilia spenops. www.fishbase.se/summary/4680, diakses 11 November 2021

Firdaus, R. A., \& Dewi, D. S. E. (2021). Efikasi Diri Dengan Kecenderungan Kecanduan Internet Pada Remaja Dimasa Pandemi Covid-19. PSIMPHONI, 1(2), 67-74.

Hakim, T. D., Amelia, V., \& Monika, W. (2021). Pkm Penyuluhan Internet Sehat Di Smk Telkom Pekanbaru. Jubaedah: Jurnal Pengabdian Dan Edukasi Sekolah (Indonesian Journal of Community Services and School Education), 1(1), 51-59. https://doi.org/10.46306/jub.v1i1.10

Humirah, L. A., Hidayati, B. N., Pratiwi*, E. A., Romadonika, F., Wasliah, I., \& Hadi, I. (2021). Hubungan Penggunaan Gadget Dan Kejadian Insomnia Pada Remaja Saat Pandemi Covid-19. Jurnal Keperawatan, 13(1), 213-226.

Razi, F. 2014. Teknik budidaya ikan black molly (Poecilia sphenops). Penyuluhan Perikanan. Pusat Penyuluhan Kelautan Dan Perikanan, Badan Pengembangan SDM KP, Kementerian Kelautan Dan Perikanan.

Sari, A. P., Ilyas, A., \& Ifdil, I. (2018). Tingkat Kecanduan Internet pada Remaja Awal. Jurnal Penelitian Pendidikan Indonesia, 3(2), 110-117.

Trobosaqua. 2020. Ikan Molly Bikin Happy, Hobi -Trobos Aqua.com, diakses 25 Februari 2021. 